\title{
Multi-population models to handle mortality crises in forecasting mortality: A case study from Hungary ${ }^{1}$
}

\begin{abstract}
CSABA G. TÓTH ${ }^{1 *}$ (D)
Hungarian Demographic Research Institute, Hungary

Received: January 11, 2021 Revised manuscript received: April 6, 2021 - Accepted: April 22, 2021

Published online: May 18, 2021

(c) 2021 The Author(s)

ABSTRACT

Central and Eastern European countries faced a serious mortality crisis in the second part of the 20th century, resulting in many years of decreasing life expectancy. In the last few decades, however, this was followed by a period in which mortality improved. This dichotomy of past trends makes it difficult to forecast mortality by way of stochastic models that incorporate these countries' long-term historical data. The product-ratio model (Hyndman et al. 2013) is a model of the coherent type, which relies more closely on subpopulations with common socioeconomic backgrounds and perspectives to forecast mortality for all populations. This paper examines whether the product-ratio model is suitable for forecasting mortality in countries that have experienced serious mortality crises. To that end, we present a case study centered on Hungary, where the mortality crisis lasted three decades. The evaluation is founded on a comprehensive comparison of the product-ratio model and the classical Lee-Carter model. Our main finding is that in the Hungarian case, the product-ratio model is more reliably accurate than the classical Lee-Carter model. The superior performance of the product-ratio model may indicate that coherent models are better suited to handling mortality crises in forecasting mortality than are independent models.
\end{abstract}

\section{KEYWORDS}

demography, mortality, life expectancy, multi-population model, mortality forecast, central and eastern europe

JEL CODE

$\mathrm{J} 00, \mathrm{~J} 10, \mathrm{~J} 14$

\footnotetext{
* Corresponding author. E-mail: toth@demografia.hu

${ }^{1}$ Thank you to Levente Pakot for his valuable support. I am also grateful for comments I received at the workshops of the Hungarian Demographic Research Institute, as well as those of two anonymous reviewers. All errors are my own.
} 


\section{INTRODUCTION}

Stochastic forecasting of mortality reached its golden age in recent decades. The revolution of IT infrastructure-together with increasing quantity and quality of relevant databases-has provided exceptional potential to improving modeling and forecasting. The springboard of this improvement process was Lee and Carter's well-known 1992 paper, which was followed by a tsunami of academic publications dealing with forecasting mortality via retrospective mathematical projections (Lee - Miller 2001; Booth et al. 2006; Brouhns et al. 2002; Renshaw - Haberman 2011). The first wave of these papers made serious and successful efforts to further develop the original Lee-Carter model, and since then, new approaches have been emerging one after the other (see Booth - Tickle 2008). The use of coherent (or multi-population) models was an important result of this period of development ( $\mathrm{Li}$ - Lee 2005; Hyndman et al. 2013). This group of models in general integrate diverse elements and relationships and put great emphasis on the logical connection and consistency of these factors. The obtained extra information may provide deeper understanding compared to the models which focus on one specific approach or agent. The defining capability of projections of this sort is to exploit the presence of cross-border patterns that shape mortality trends. Using information from the co-movement (or lack thereof) of the mortality rates of different countries may help to improve projections' robustness and accuracy. Simultaneously, these models also apply the approach and method by which the Lee-Carter model revolutionized mortality forecasting.

In addition to the chosen method, a forecast's efficiency largely depends on the character of the given time series, which explains variation in the usefulness of models between regions with different demographic backgrounds. This distinction holds true in the cases of Western European and formerly socialist countries as well. While mortality decreased relatively gradually and more or less continuously in Western European countries over the last 70 years, structural breaks and periods of stagnating or even increasing mortality (i.e., mortality crises) emerged in post-socialist countries, especially among men (Meslé - Vallin 2002). Although the mortality crises of these post-socialist nations significantly differed in terms of length, extent, and coverage, they each make it problematic to forecast mortality by way of the Lee-Carter model. This is especially true in Hungary, whose mortality crisis was significant and has a sizable impact on projections.

Shang (2015) conducted comprehensive research from which he concluded that the multipopulation forecasting techniques such as the product-radio model (Hyndman et al. 2013) "should receive further attention and be considered as a benchmark method for producing the best estimates of age-specific mortality rates and life expectancies of males" (Shang 2015: 331). There are other mortality forecasts based on the multi-population approach, but to the best of our knowledge, there are few studies that compare coherent and non-coherent methods for countries that have experienced historical mortality crises. Shang (2015) investigated mainly developed West-European and North-American countries, Shair et al. (2017) focused on Australia and Malaysia, and although Rabbi and Mazzuco (2018) analyzed Central and Eastern European countries, they applied an early (and simpler) type of coherent model (Li - Lee 2005). This paper's novel contribution is to evaluate the accuracy of a complex and more recent multipopulation model (Hyndman et al. 2013) for a country that has undergone a serious mortality crisis. 
Specifically, we address the following research question: in forecasting Hungarian mortality, do we obtain more accurate and plausible results from the product-ratio model of Hyndman et al. (2013) - one of the well-known multi-population models-than from the traditional LeeCarter model? To answer this question, we forecast Hungarian mortality with both models in order to compare the results and evaluate them from several perspectives. When applying the product-ratio method, the three other nations of the Visegrad Group (Czechia, Poland, and Slovakia) are included as reference countries.

In the next section, we briefly summarize Hungary's mortality trend since the Second World War, identifying the structural breaks and mortality crisis that make feasible projection more difficult. We then present a survey of the relevant literature, focusing on the different methods used thus far to forecast Hungarian mortality. The fourth section summarizes the mathematical background of the Lee-Carter model and gives a detailed description of the product-ratio model's innovations. In the following section, we introduce the models' parameters. The sixth section details the results obtained from each model, which we compare from several perspectives. Conclusions are drawn in the seventh and final section.

\section{MORTALITY TRENDS IN HUNGARY}

To achieve a global understanding of the history of Hungarian mortality, it is worthwhile to discuss it in the European context. This is also particularly useful to the coherent forecasting approach that we apply, as it provides information about the potential countries that can later be included in the prediction.

In the 1960s, after a brief general slowdown of life-expectancy increases in most European countries, a long-lasting period of divergence began between Western European and communist countries (Meslé 2004; Caselli et al. 2002, Bobak - Marmot 1996). The former stepped into the period of the cardiovascular revolution (Olshansky - Ault 1986), taking advantage of the development of healthcare systems-a process strengthened by a growing societal awareness of health. All this contributed to continuous and significant increases in life expectancy among both males and females over the coming decades (Meslé - Vallin 2012). The situation in communist countries differed starkly. They proved unable to benefit from the cardiovascular revolution, suffering from the spread of man-made diseases and surges in violent deaths. This created a mortality crisis, majorly setting back the life expectancies of both sexes, but especially of males.

While these communist countries seemed to follow a similar pattern for the first few decades, the different lengths of this period revealed differences between the countries of the former Soviet Union and the other Central European states (Meslé - Vallin 2017). Based on these turning points, it has proved more reasonable to differentiate the two groups. While the deviation from Western European trends continued to widen in the countries of the former Soviet Union until the mid-2000s, Central European countries' mortality crises ended earlier, in the 1990s (Meslé - Vallin 2012; Luy et al. 2011; Grigoriev et al. 2014). In other words, after 30 years of setbacks, a new period began in Central Europe, marked by dynamic increases in the life expectancies of both sexes. The Czech Republic (Rychtaříková 2004) was the first to experience this trend, and it was soon followed by Poland, Slovakia, and Hungary; some years later, Romania and Bulgaria began to see the same improvements (Meslé - Vallin 2017). Despite some 
variation, even in this region, of the year in which life-expectancy trends reversed, the main drivers of this change were similar across Central European countries. The fall of the Berlin Wall allowed the speedy adoption of new tools and techniques in healthcare, and the transition of political and socioeconomic regimes contributed to a slower, but equally remarkable transformation of individual behaviors (Fihel - Pechholdova 2017; Fihel - Okólski 2019). These changes resulted in large-scale advances in reducing cardiovascular and man-made diseases and contributed to the entire region's catching up, in terms of life expectancy, with Western Europe.

In general, the above trends could be observed in Hungary as well (Fig. 1; see also Bálint 2016; Valkovich 1999; Józan 2002; Kovács 2012). The dynamic growth of life expectancy for women slowed down by 1966, increasing from just 72.2 years to 73.9 between then and 1994 . Male life expectancy dropped from 67.5 years to 64.6 years in the same period. Beyond general explanations, we argue that the prevalence of smoking had a strong effect on the increasing incidence of neoplastic diseases (Laczkó 2010); meanwhile, the extreme quantity of alcohol consumption left its marks on the explosive growth of diseases of the digestive system (Józan 2003), and the exceptional number of suicides increased the occurrence of violent deaths (Buda 2001; Bálint 2008). The significant differences that developed between males and females in timing, and in the extent of the impact of the above factors, explains the milder deterioration of mortality among women, relative to the more significant decline among men.

The sudden shift in mortality trends reached Hungary a few years after its political transition, since the regime change itself was a painful shock therapy for the country (Stuckler et al. 2009; Scheiring et al. 2018). More than a million people lost their job (Fazekas 1997; Fazekas Scharle 2012) the prices suddenly jumped high (Golinelli - Rovelli 2002), the predictability, which was experienced in the previous decades disappeared from one moment to the next (Spéder et al. 1998). Moreover, the state budget was unable to effectively moderate the

Females

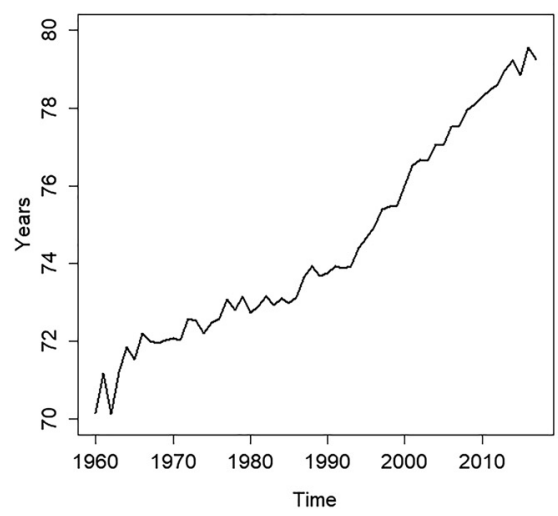

Males

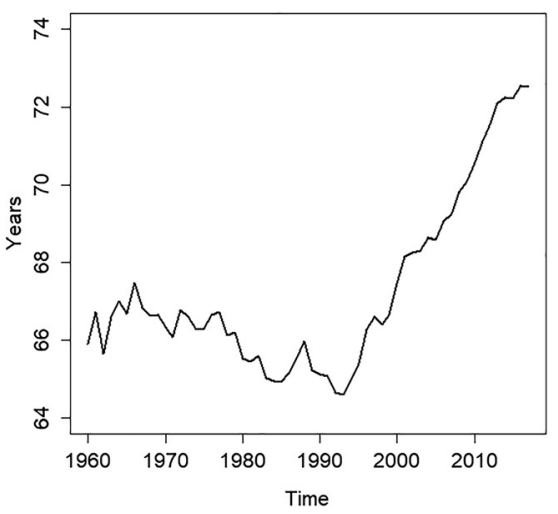

Fig. 1. Life expectancy at birth in Hungary from 1960 to 2017 Source: Human Mortality Database. 
short-term disadvantage of the economic transformation, since the increasing deficit and public debt itself already risked the sustainability of fiscal policy (Benedek et al. 2006; Muraközy 2008).

However, in the middle of that decade, a new period began. It was driven on the one hand by the moderation of alcohol and cigarette consumption (Józan 2004; Bálint 2016), the spread of healthier nutrition, and a decreasing number of suicides (Józan 2008). On the other hand, this improvement was dynamized by the development of healthcare systems, and the growing efficiency and availability of medicines. This fits to the main findings of the empirical literature which provides strong evidence on the role of affordability (Sommers et al. 2014; Woolhandler - Himmelstein 2017), accessibility (Prentice - Pizer 2007), and physical activity (Johansson - Sundquist 1999) on life prospects and mortality. As a result, the average annual growth of female life expectancy jumped to 0.22 in the next 20 years, compared to the 0.06 of the previous 30 . The change was even more dramatic for men, whose average annual growth of life expectancy grew from -0.11 to 0.33 .

The background of the differences between male and female life expectancies can be captured by the changes of age-specific mortality rates, which also reveal the primarily agerelated character of the mortality crisis (Fig. 2). These rates indicate that the youngest generation (under 20) and the oldest generation (above 80) remained unaffected by the unfavorable trends which took place from the middle of the 60 s till the middle of the 90 s. Rather, the mortality crisis hit the middle generations the hardest. In the case of males, the increase of mortality was considerably steep. It spanned 30 years, affecting those aged between 40 and 70 . The growth of mortality among females proved to be softer and shorter in duration, mainly affecting those aged 40 to 60 . Since mid-1990s, both sexes bounced back strongly, especially at those ages that had been most affected by the mortality crisis.

The reason that this brief summary of Hungarian mortality trends is provided is to describe the extent and background of the structural break in the time series. This is the issue that challenges the classical Lee-Carter method of forecasting mortality and incentivizes us to handle the time series by way of coherent forecasting. By the use of the latter, we can employ convergences with (and divergences from) the mortality rates of countries with similar histories in order to improve the efficiency of the forecast.
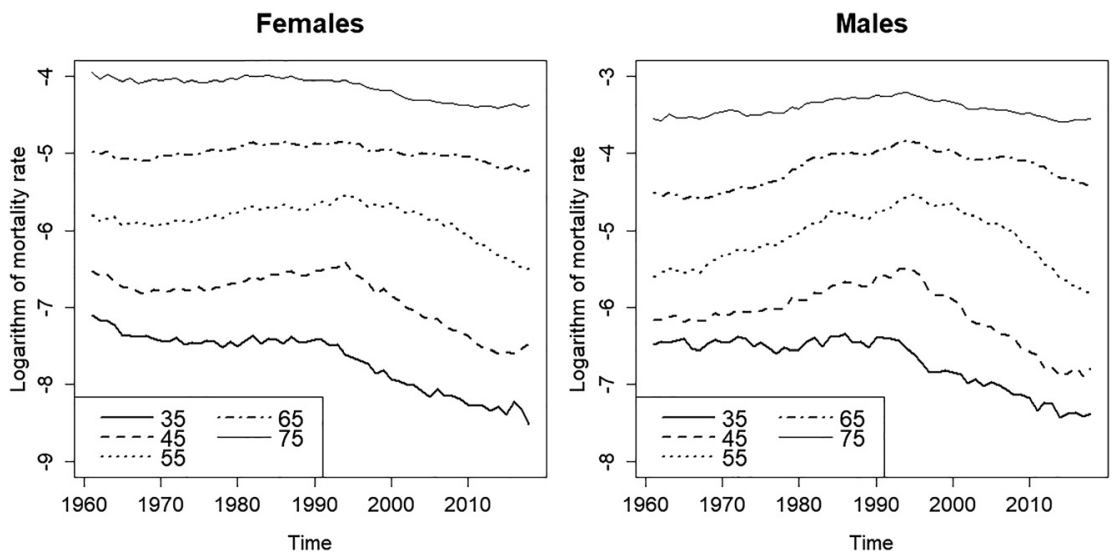

Fig. 2. Age-specific mortality in Hungary from 1960 to 2017 Source: Human Mortality Database. 


\section{FORECASTING HUNGARIAN MORTALITY}

Several excellent academic papers were published in recent decades that contained stochastic forecasts of Hungarian mortality. Although many different methods were applied, and some achieved creditable progress in reforming methodology, a significant portion of these publications focused on issues other than forecasting (and publishing) the mortality of the whole population. Several of them used the approach of actuaries and concentrated on forecasting mortality among those aged 65 years and older (Májer - Kovács 2011; Vékás 2017). Other researchers presented new methods (Arató et al. 2009; Vékás 2018; Petneházy - Gáll 2019) or focused on comparing the accuracy of different methods (Hatzopoulos - Haberman 2013; Anghel - Solomon 2015) without publishing the details of the forecast. Still, there are certain relevant articles that can be considered the antecedents of this paper.

Baran et al. (2007) were the first to adapt the Lee-Carter model to forecast Hungarian mortality, but even the results of their early work pointed to the primary challenge of applying the Lee-Carter model in Hungary. When the researchers used the complete historical database from 1949 to 2003 to forecast mortality in 2040, they arrived at a predicted increase of mortality for 50-year-old males, which is unrealistic on the one hand and the obvious consequence of the mortality crisis described above on the other. Although they obtained plausible and convincing results after narrowing the base period to 1989-2003, they concluded that the Lee-Carter model did not provide a sufficiently trustworthy forecast because of the relatively high standard errors associated with the small size of datasets employed. Their initial comments regarding the mortality crisis' distorting effect on the forecast remained valid; this is confirmed by Bohk and Rau (2015), who used data from 1965 to 1990 in the Lee-Carter model to forecast Hungary's 2009 mortality rates for males and females. The pair then compared their predictions with the real 2009 data, finding that their forecast had not yielded accurate predictions.

Building on the second finding of Baran et al. (2007) - that the difficulties in forecasting were attributable to the short time series-Bajkó et al. (2015) later took advantage of the passage of time by repeating the examination with a longer base period (1980-2012). The researchers received plausible results, but it should be emphasized that their forecast period was about two thirds of their fitting period. This points to an issue: if we observe both caution and convention (Booth et al. 2002), according to which the maximum length of the forecast period should be approximately the same as that of the fitting period, it imposes a serious limitation on the usability of the Lee-Carter model, owing to the short duration of the time series since the end of the mortality crisis.

A comprehensive and relevant analysis regarding the use of various forecasting methods for high(er)-mortality countries was published by Rabbi and Mazzuco (2018). They compared the accuracy of several different forecasting models for several Central and Eastern European (CEE) countries. Their comparative analysis did not include the product-ratio model (Hyndman et al. 2013) that we apply here, but they investigated the efficiency of another coherent model (Li Lee 2005) whose working mechanism is, to some extent, similar to that of the product-ratio model. ${ }^{2}$ In the Hungarian case, Rabbi and Mazzuco (2018) found that the Lee-Carter model is one of the least efficient methods of forecasting mortality, especially for males. The most efficient forecast was produced by the model of Hyndman and Ullah (2007), but the model of Booth et al.

${ }^{2}$ Greater detail is available in the next chapter. 
(2002) and that of Li and Lee (2005) achieved reasonably good scores as well. This is very promising for us, since the product-ratio model we apply is based on these three models and incorporates several of their features. This also means that our paper can be considered an extension of the research conducted by Rabbi and Mazzuco (2018).

\section{METHODOLOGY: FROM THE LEE-CARTER TO THE PRODUCT-RATIO MODEL}

Although it had important and noteworthy predecessors, there is no doubt that the emergence of the Lee-Carter model (1992) brought mortality forecasting into a new age. The Lee-Carter model's simplicity and accuracy made it extremely popular worldwide, and soon it became "the leading statistical model of mortality in the demographic literature" (Deaton - Paxson 2004: 264). The power of this model is to apply several different techniques of time series analysis on historical data to forecast mortality. Its original core is the following equation:

$$
\log \left[m_{t}(x)\right]=a(x)+b(x) k_{t}+\varepsilon_{t}(x)
$$

where $m_{t}(x)$ is the central death rate at age $\mathrm{x}$ in year $\mathrm{t}, a(x)$ is the estimated age profile of the log mortality rates averaged over the years, $b(x)$ represents the first estimated principal component reflecting relative change in log mortality rate at each age, and $k_{t}$ is a time-varying index capturing the overall level of mortality in year t. Constraints are imposed to obtain a unique solution, so the $a(x)$ are set equal to the means over time of $\log \left[m_{t}(x)\right]$, the $b(x)$ sum to 1 , and the $k_{t}$ sum to 0. Lee and Carter (1992) applied Singular Value Decomposition (SVD) to obtain the parameters of the equation, and then they extrapolated $k_{t}$ by using ARIMA time series models. Lee and Carter used a random walk with drift model, and although they did not prescribe it for all situations, this model has been proved to be appropriate in almost all cases (Both et al. 2006). In the next chapters, when we use the Lee-Carter model to forecast Hungarian mortality, we employ the variant developed by Lee and Miller (2001), whose suggestions are widely accepted fine-tunings, but leave unchanged the structure of the original model (Tóth 2021). The Lee-Miller variant introduced three useful modifications: (i) adjustment of $k_{t}$ to fit $m_{t}(x)$ in year $t$, (ii) setting the earliest commencement of the fitting period to 1950, and (iii) using the actual rate of mortality as $a(x)$ instead of the average for the whole fitting period.

For almost the last thirty years, there has been a steady flow of papers that drew attention to the weaknesses of the Lee-Carter model. From several different approaches, these works have also made serious efforts to renew or improve the original model. Some of them revealed that the model falls short of accounting for the cohort effect (Renshaw - Haberman 2006; Renshaw Haberman 2011); others questioned the distribution of standard errors (Wilmoth 1993; Brouhns et al. 2002) or introduced a new analytical procedural framework that uses a generalized linear model (Villages et al. 2015).

In the following chapters, we forecast Hungarian mortality with the product-ratio model that Hyndman et al. published in 2013. We have chosen this particular model because it entails three innovative improvements to the Lee-Carter model; we assume these innovations to be able to resolve the difficulties inherent in forecasting the mortality of a country with a significant mortality crisis in its past. We explore these three features-a functional data approach, the product-ratio method, and the use of additional principal components-in greater detail below. 
The use of a functional data approach, which Hyndman and Ullah earlier introduced in 2007, is an important difference between the product-ratio model and the Lee-Carter model. Hyndman and Ullah treated the underlying process as functional and used nonparametric smoothing to reduce some of the inherent randomness in the observed data. To understand the details, suppose that $y_{t}(x)=\log \left[m_{t}(x)\right]$. In the functional data paradigm, we assume that there is an underlying smooth function $f_{t}(x)$ that we are observing with error. Thus,

$$
y_{t}\left(x_{i}\right)=\log \left[f_{t}\left(x_{i}\right)\right]+\sigma_{t}\left(x_{i}\right) \varepsilon_{t, i}
$$

where $x_{i}$ is the center of age group $i(i=1, \ldots p), \varepsilon_{t, i}$ is an independent and identically distributed standard normal random variable, and $\sigma_{t}\left(x_{i}\right)$ allows the amount of noise to vary with age $\mathrm{x}$. According to Hyndman et al. (2013), it is advisable that smoothing use weighted penalized regression splines (Wood 1994) constrained so that each curve is monotonically increasing above age $\mathrm{x}=65$. This monotonicity constraint allows us to reduce the noise in the estimated curves for high ages (Hyndman - Ullah 2007).

The main innovation of the product-ratio model itself is the product-ratio method, from which it got its name. This is how the model forecasts mortality for groups or subgroups with two or more members. This method can be viewed as a generalization of the $\mathrm{Li}$ and Lee (2005) approach (Hyndman et al. 2013 p. 280). ${ }^{3}$ The core of the product-ratio method is to split the tendency of a subpopulation's mortality into a general trend, which describes the mortality change of all subpopulations (product function), and another time series, which captures divergences from the main trend (ratio function) for each population. In the next step, these functions are forecast separately. This method is based on the assumption that subpopulations' future mortality trends will be driven, in addition to by their own particular mortality histories, primarily by the general trend that governs all subpopulations. Hence, the main driver is the product function, which is driven by the geographical average of the subpopulations and adjusted by the ratio function. The latter accounts for the unique character of each country. Coherence is ensured by the convergence of the ratio functions toward constant age-specific ratios. However, it should be noted that this convergence toward constant ratios does not imply that mortality differences between subpopulations tend to a set of constants. Rather, trends in forecast differences depend on both the ratio and product functions. Divergence and constant differences are similarly constrained and, for most populations, are unlikely to be forecast, given observed mortality trends (Hyndman et al. 2013: 276).

The two new (product and ratio) functions are defined by the smoothed rates of subpopulations. If there are more than two subpopulations, then

and

$$
p_{t}(x)=\left[f_{t, 1}(x) f_{t, 2}(x) \ldots f_{t, J}(x)\right]^{1 / J}
$$

$$
r_{t, j}(x)=f_{t, j}(x) / p_{t}(x)
$$

\footnotetext{
${ }^{3} \mathrm{Li}$ and Lee (2005) were the first to apply the Lee-Carter model to jointly forecast the mortality of multiple distinct populations. First, they identified a common trend of mortality change in these populations. Next, they extended it by a specific factor of a subpopulation, which contained the first-order vectors derived from applying the SVD to the residual matrix of the common model.
} 
where $J$ is the number of subpopulations, $j=1, \ldots J$, and $p_{t}(x)$ is the geometric mean of the smoothed rates and so represents the joint (nonstationary) behavior of all subpopulations. The correlation between the product functions $p_{t}(x)$ and each set of ratio functions $r_{t, j}(x)$ is approximately zero. The ratio functions satisfy the constraint $r_{t, 1}(x)+r_{t, 2}(x)+r_{t, J}(x)=1$. In the next step, functional time series models are applied for $p_{t}(x)$ and each $r_{t, j}(x)$ for $j=1, \ldots J$ :

$$
\begin{aligned}
\log \left[p_{t}(x)\right] & =\mu_{p}(x)+\sum_{k=1}^{K} \beta_{t, k} \phi_{k}(x)+e_{t}(x) \\
\log \left[r_{t, j}(x)\right] & =\mu_{r, j}(x)+\sum_{l=1}^{L} \gamma_{t, l, j} \psi_{l, j}(x)+\omega_{t, j}(x)
\end{aligned}
$$

where the functions $\phi_{k}(x)$ and $\psi_{l, j}(x)$ are the principal components obtained from decomposing $p_{t}(x)$ and $r_{t, j}(x)$, respectively, and $\beta_{t, k}$ and $\gamma_{t, l, j}$ are the corresponding principal component scores. The function $\mu_{p}(x)$ is the mean of the set of curves $p_{t}(x)$, and $\mu_{r, j}(x)$ is the mean of $r_{t, j}(x)$. The error terms, given by $e_{t}(x)$ and $\omega_{t, j}(x)$, have zero mean and are serially uncorrelated. Using Eqs (4), (5a), and (5b) we can simplify for all subgroups:

$$
\log \left[f_{t, j}(x)\right]=\log \left[p_{t}(x) r_{t, j}(x)\right]=\mu_{j}(x)+\sum_{k=1}^{K} \beta_{t, k} \phi_{k}(x)+\sum_{l=1}^{L} \gamma_{t, l, j} \psi_{l, j}(x)+z_{t, j}(x)
$$

where $\mu_{j}(x)=\mu_{p}(x)+\mu_{r, j}(x)$ is the group mean, and $z_{t, j}(x)=e_{t}(x)+\omega_{t, j}(x)$ is the error term.

The third important feature that distinguishes the product-ratio model from the Lee-Carter model is indicated by the two middle terms on the right side of Eq. (6). Hyndman et al. (2013) used additional principal components, a method introduced by Booth et al. (2002). The latter pointed out that the Lee-Carter model made use only of the first term of the SVD, but the second and higher-order terms were worthy of incorporation as well. This is quite sensible: any systematic variation in the residuals from fitting only the first term would be captured by the second and higher terms. The additional principal components capture patterns in the data that supplement the main trend and may be significant. Hyndman et al. (2013), like Hyndman and Ulla (2007), used up to six principal components, although in practice, only the first two have significant effects for mortality. This feature is extremely important for a country like Hungary, which experienced structural breaks and significant divergences beyond the main trend. Approached from another angle, it is worth recognizing that the additional components provide that the modeled death rates are no longer perfectly correlated across age, unlike in single-component models.

The final step is to independently forecast the obtained coefficients. The coefficients of the product model $\left(\beta_{t, 1}, \ldots \beta_{t, K}\right)$ are forecast using possibly nonstationary autoregressive integrated moving average (ARIMA) models without restriction. For the coefficients of the ratio model $\left(\gamma_{t, 1, j}, \gamma_{t, 2, j} \ldots \gamma_{t, L, j}\right)$, Hyndman et al. (2013) use an autoregressive fractionally integrated moving average (ARFIMA) (p, d, q) process to forecast because it provides for longer-memory behavior than is possible with ARIMA models. The stationarity requirement ensures that the forecasts are coherent, and the use of ARFIMA ensures that ratios of the forecasted age-specific death rates from any two subpopulations converge toward the weighted historic mean ratios as the constants.

The goal of this chapter was to summarize the main features of the product-ratio model, as compared with the Lee-Carter model. In accordance with these features, we assume that the product-ratio model is capable of providing a more efficient mortality forecast for Hungary. These improvements cover various aspects of forecasting. Smoothing the data by introducing 
the functional data approach seems a reasonable tool in general, and using additional principal components may be suitable for countries with a historical mortality crisis. Incorporating additional subpopulations into the forecast by the product-ratio method prevents subpopulations from diverging because of temporary country-specific characteristics, thereby ensuring the coherence of the forecast.

\section{DATABASE AND REFERENCE GROUP}

In order to ascertain whether the product-ratio model is more suitable than the Lee-Carter model for forecasting mortality in countries with sizable mortality crises in their pasts, we forecast Hungarian mortality via both methods and compare the results. Data for both analyses are drawn from the Human Mortality Database (HMD 2020). Because we are curious about which method best fits countries with historical mortality crises, we use the longest fitting period possible. The editors of the Human Mortality Database note that the quality of Hungarian data from 1950 to 1959 is lower than in later years and should be used with caution; accordingly, we use mortality data from 1960 to 2017 to forecast the period 2018-2050. The evaluation involves fitting the different methods to data up to 2007, forecasting for the period 2008-2017, and comparing the forecasts with that period's actual mortality. The data consist of central death rates by sex and by single year of age, through 95 years.

When applying the product-ratio model, we use the three other members of Visegrad Group (Czechia, Poland, and Slovakia) as reference countries. The inclusion of these countries can be supported by wide socioeconomic arguments in addition to empirical, mortality-specific ones. The former are based on the shared socialist-era history of Visegrad Group nations and the common patterns of development after transitioning away from socialist regimes. Although various differences exist between these countries, the theory of path dependence (Csaba 2007; Dyba et al. 2018) argues that their similarities in socioeconomic circumstances, including those factors that shape mortality, make it suitable for us to treat

Females

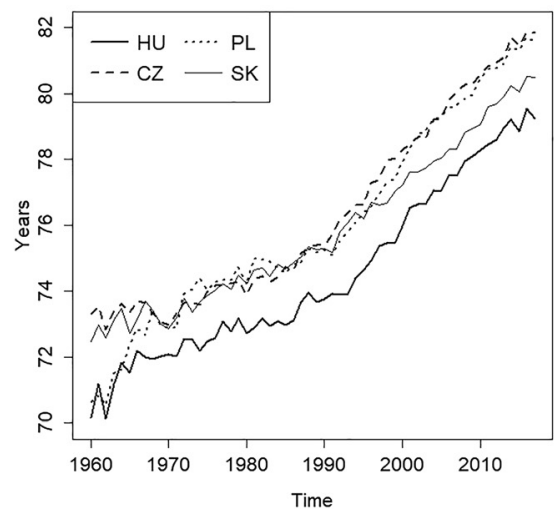

Males

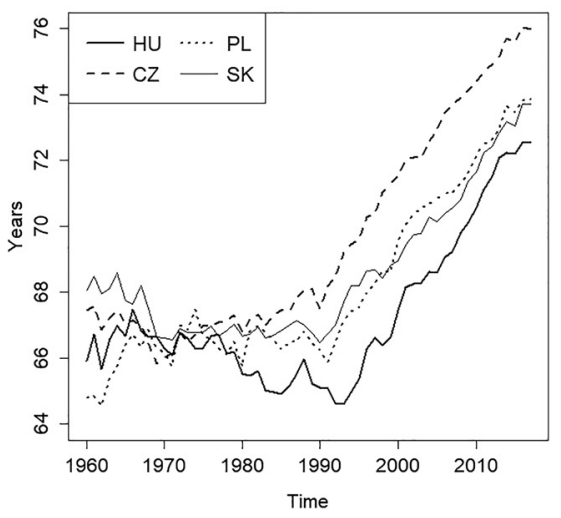

Fig. 3. Life expectancy at birth in Visegrad Group countries from 1960 to 2017 Source: Human Mortality Database. 
them as a group in modeling mortality (Dãnãcicã 2006; Šimpach 2014; Rabbi - Mazucco 2018).

This view is strengthened by the Visegrad Group nations' common historical mortality trends as well (Fig. 3). Certainly, a number of minor differences in scale and timing exist, but in general, the mortality crisis tangibly struck all four countries in the second half of the prior century. Similarly, after the tipping point of the transition away from socialism, a more dynamic increase in life expectancy can be observed across the entire region.

The statistical approach also underpins our choice. Using life expectancy at birth for the fitting period (1960-2017), we calculated correlation ratios and standard deviations of differences for each European country to measure their co-movement with Hungarian mortality for both sexes. Slovakia, Poland, Czechia, and Romania were consistently the top-five performers in terms of correlation ratios and standard deviations of differences for both females and males. Romania was not included in the reference group because its mortality data is not contained within the Human Mortality Database.

\section{COMPARISON OF THE RESULTS}

In this chapter, we compare and evaluate-in several dimensions-the forecasts of Hungarian mortality drawn from the Lee-Carter model and the product-ratio model. First, we present the mortality curves to observe the differences between the two forecasts (Fig. 4). For easier interpretation, we also show the levels of mortality at the beginning and the end of the fitting period, and to avoid any misinterpretation that might arise from outliers in those timeframes, we use the averages of the first three years (1960-1962) and the last (2015-2017). As a reminder, the relatively small differences between the beginning and the end of the fitting period at some ages, especially from 40 to 60 , is the sum of the increasing mortality prior to the transition and the decreasing mortality after it.
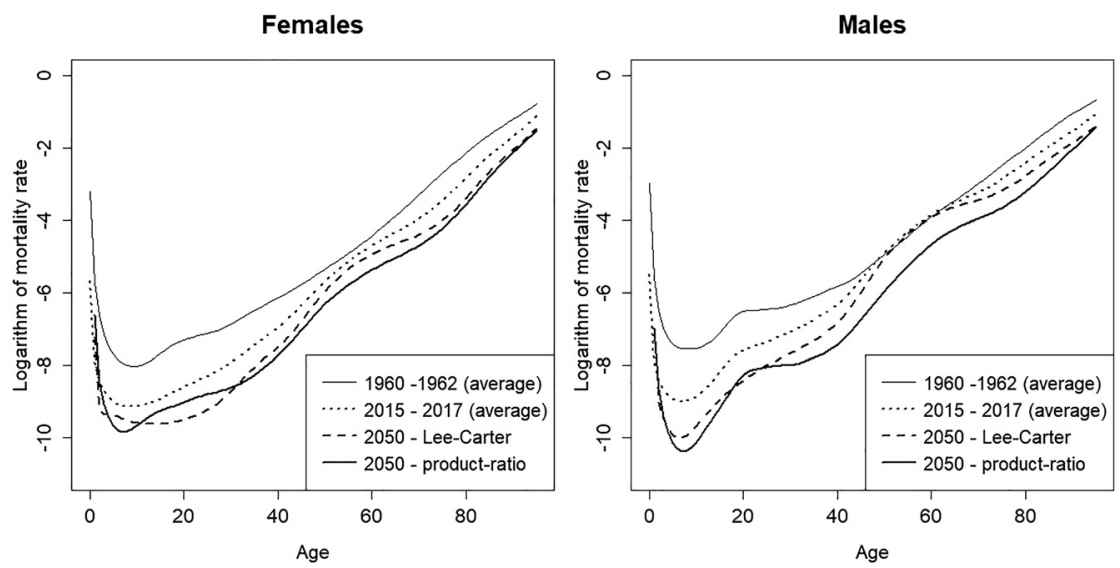

Fig. 4. Forecast of 2050 mortality rates by Lee-Carter and product-ratio models with first and last years of fitting period

Source: author. 
The central problem with the Lee-Carter model is obvious at first glance: there is hardly any improvement between 2017 and 2050 in the mortality of the middle-age generations of both sexes, which we assume can be explained by the historical mortality crisis and the way it is (mis) handled by the Lee-Carter model. The weakness of the Lee-Carter model's forecast is more serious in the case of males, just like the mortality crisis itself, but it threatens the plausibility of the forecast for females as well.

The product-ratio model clearly proves more successful in solving this problem for both sexes. It predicts a notable and plausible improvement in mortality for middle-age generations, and it more realistically forecasts mortality at large in 2050 for both men and women.

The differences between the forecasts can be more easily captured by the predicted changes in age-specific mortality rates (Fig. 5). For the middle generations, we can observe a bump, which arises out of the increase of mortality in the first 30 years of the fitting period and its sharp decline in the last decades. This decline is spectacular at age 40 for both sexes, but for males, it is also observable at the ages of 55 and 70. In those cases, the predictions of the Lee-Carter models are too flat; it seems that the Lee-Carter model's estimations do not consider the improvements in mortality present in the last decades.

This can be attributed to the fact that the Lee-Carter model uses only the first term of the SVD, and a single-component method is unable to handle the structural breaks in the time series. The advantage of the product-ratio model in these generations is convincing. The trend of forecasted mortality is driven primarily by the experience of the last decades, due to the use of additional principals, and the utilization of information about the mortality of the reference group.

Using the forecast of age-specific mortality rates, we have computed the changes in life expectancy at birth from both models (Fig. 6). According to the Lee-Carter model, female life expectancy at birth in 2050 is predicted to be 82.6 , with a relatively wide 4.5 -year prediction interval (we use an $80 \%$ prediction interval in forecasting life expectancy). According to the product-ratio model, female life expectancy at birth will be 84.5 , with a narrower 2.4 -year prediction interval. Considering that the final datapoint of the fitting period (2017) was 79.3 years, we find that the average annual growth of life expectancy until 2050 is 0.10 according to
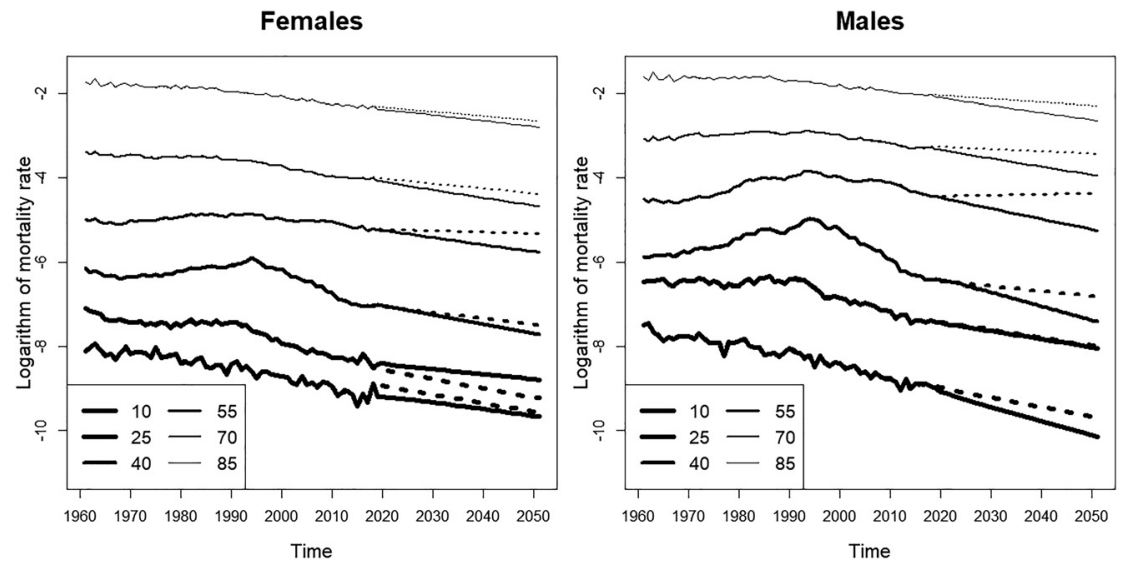

Fig. 5. Forecast of age-specific mortality rates by Lee-Carter (dotted) and product-ratio (solid) models Source: author. 

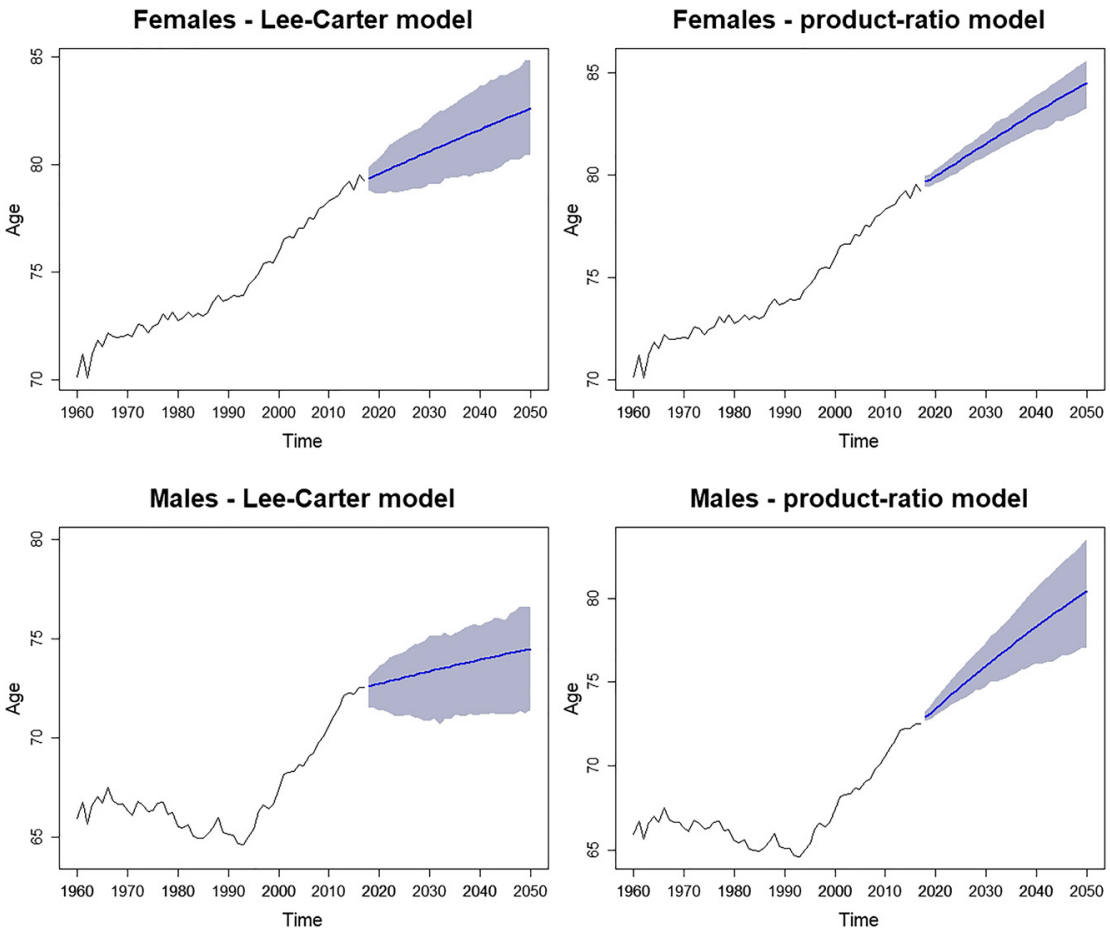

Fig. 6. Forecast of life expectancy at birth by Lee-Carter (left column) and product-ratio (right column) models

Source: author.

the Lee-Carter model and 0.16 as forecast by the product-ratio model. Both predictions foresee a slowdown in the coming decades, compared to the period between 1990 and 2017, when the average annual growth of life expectancy for females was 0.20 years.

The differences are more pronounced for males. Per the Lee-Carter model, male life expectancy at birth increases from 72.5 to just 74.5 by 2050 , with a 5.1 -year prediction interval, while the product-ratio model predicts a male life expectancy at birth of 80.4 years in 2050, with a 6.2-year prediction interval. This means that the last few decades' (19902017) annual increase in life expectancy, 0.28 , would drop to 0.06 in the forecast of the Lee-Carter model, whereas it remains stable, around 0.24 , when calculated via the productratio model.

To evaluate and compare the accuracy of the two methods, we also conducted an out-ofsample analysis for which we cut the fitting period at 2007, forecast mortality through 2017, and compared the predicted life expectancy at birth to the observed value (Fig. 7). The Lee-Carter model predicted female life expectancy at birth of 78.6 years in 2017, which is somehow lower than the observed 79.3 , but the latter is covered by the relatively large $80 \%$ prediction interval $(2.7$ years). Using the product-ratio model, our point estimation is 79.3 years, which is proximal to the observed value. The product-ratio model's prediction interval, at 1.3 years, is also narrower. 

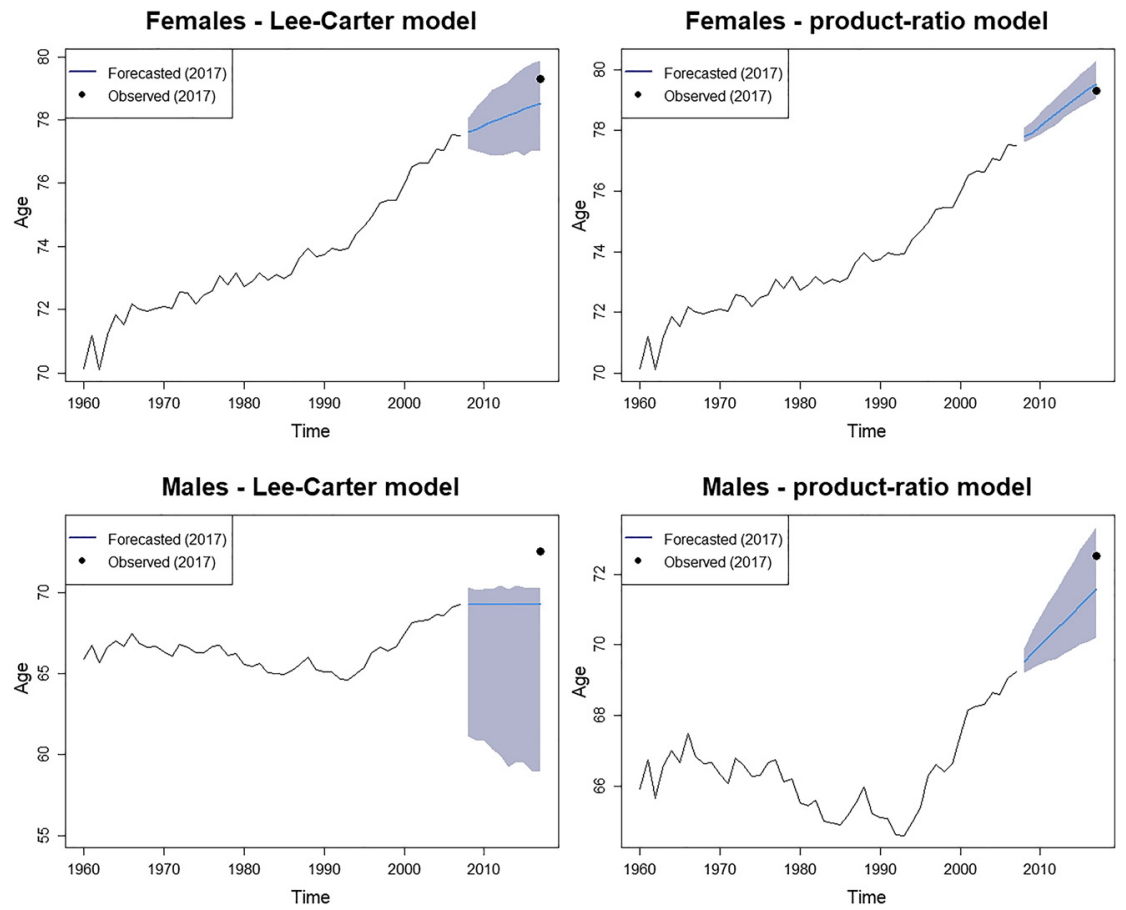

Fig. 7. Out-of-sample forecast of life expectancy at birth by Lee-Carter (left column) and product-ratio (right column) models and the observed value in 2017

Source: author.

The use of the Lee-Carter model to produce a 10-year forecast for men based on the shorter fitting period (1960-2007) yielded implausible results: a predicted life expectancy in 2017 of 69.2 years, compared to the observed life expectancy of 72.5, and an enormous and asymmetric prediction interval (58.3-70.3 years). We obtained a superior result with the product-ratio model, according to which life expectancy at birth of males was to grow to 71.6 years by 2017 . This is less than one year lower than the observed value, and the latter is covered by a relatively narrow prediction interval: 70.2 years -73.5 years.

In order to include the whole forecast period (2008-2017) in the evaluation, rather than using the last year (2017) alone, we applied a statistical indicator to measure accuracy. The mean absolute percentage forecast error (MAPFE) is a suitable research tool for revealing the differences between the efficacies of the two models (see Shair et al. 2017).

$$
M_{A P F E}=\sum_{t=1}^{T}\left|\left(F_{n+t}-E_{n+t}\right) / E_{n+t}\right|^{*} 100 / T
$$

Where $F$ is the forecasted life expectancy at birth, $E$ is the observed value, $n$ is the last year of the fitting period and $t=1 \ldots T$ is the number of predicted years.

For females, the indicator computed by the prediction of the Lee-Carter model is more than three times higher than the corresponding value under the product-ratio model (Table 1). The 
Table 1. Mean absolute percentage forecast error (MAPFE) of life expectancy at birth for males and females under both methods (2008-2017)

\begin{tabular}{|l|c|c|}
\hline MAPFE & Lee-Carter model & product-ratio model \\
\hline & 0.83 & 0.26 \\
\hline Females & 3.35 & 1.29 \\
\hline Males & & \\
\hline
\end{tabular}

Source: author.

direction of difference is the same for males, with a slightly smaller size. It is not surprising that the forecast error is more than four times higher for males than for females, regardless of the method of prediction, since the mortality crisis that complicates the forecasting process was more serious and pronounced among men. The fact that the forecasting error is considerably higher with the Lee-Carter model than the product-ratio model strengthens our previous finding of superior performance, insofar as accuracy, by the product-ratio model.

Our results also conform to the findings of the literature. Shair et al. (2017) compared the accuracy of mortality forecasting for Australia and Malaysia, and in both countries, the forecasted error proved higher for independent Lee-Carter models than for the coherent model. Shang (2015) also found, by evaluating the forecast accuracies of several different models for 20 developed countries, that the coherent model had the smallest forecast error in the male case for long forecast horizons.

\section{CONCLUSION}

Hungary faced a serious mortality crisis in the second part of the 20th century. The period of decreasing life expectancy began in the mid-1960s and lasted 30 years for males, and the life expectancies of females also deteriorated substantially in comparison with previous periods. In the decades that followed, a relatively speedy decrease of mortality could be observed. This sharp dichotomy in mortality history that characterizes the whole of Central and Eastern Europe, as well as the post-Soviet countries, creates serious difficulty in forecasting mortality by way of stochastic mathematical models.

In this paper, we applied one of the well-known multi-population models (Hyndman et al. 2013) to forecast Hungarian mortality in order to evaluate how it handles mortality crises. This product-ratio model makes three important improvements on the classical Lee-Carter model: it uses smoothed data by introducing a functional data approach, it accounts for the evolution of mortality in other countries (assuming that a common socioeconomic background provides a common trend in mortality), and it applies additional principal components compared to the classical Lee-Carter model. This latter modification is a useful tool in general, especially if there are any structural breaks in the time-series which we are going to forecast.

To evaluate the efficiency of these improvements, we forecast Hungarian mortality via both the product-ratio model and the Lee-Carter model, and we compared the accuracy of the two forecasts across a number of dimensions. In the case of the multi-population approach, we used 
the three other members of the Visegrad Group (Czechia, Poland, and Slovakia) as reference countries. We found that the product-ratio model provides a superior forecast, which demonstrates that the above-mentioned improvements on the Lee-Carter model may be able to increase the accuracy of mortality forecasts in countries that have experienced mortality crises.

\section{REFERENCES}

Anghel, L. - Solomon, C. I. (2015): Longevity Impact on the Life Annuities on Romania by Comparative Analysis with Bulgaria and Hungary. https://www.researchgate.net/publication/280254785, accessed 22/04/2021.

Arató, M. - Bozsó, D. - Elek, P. - Zempléni, A. (2009): Forecasting and Simulating Mortality Tables. Mathematical and Computer Modelling 49(3-4): 805-813.

Bajkó, A. - Maknics, A. - Tóth, K. - Vékás, P. (2015): A magyar nyugdíjrendszer fenntarthatóságáról [The sustainability of the Hungarian pension system]. Közgazdasági Szemle 62(12): 1229-1257.

Bálint, L. (2016): Mennyire illeszkedik a magyar halandóság alakulása az epidemiológiai átmenet elméleteihez? [Do Hungarian mortality trends fit the theory of epidemiological transition?] Demográfia 59(1): 5-57.

Bálint, L. (2008): Öngyilkosságok Magyarországon - néhány területi jellegzetesség [Suicide in Hungary regional characteristics]. Területi Statisztika, 11(48): 573-591.

Baran, S. - Gáll, J. - Ispány, M. - Pap, G. (2007): Forecasting Hungarian Mortality Rates Using the LeeCarter Method. Acta Oeconomica 57(1): 21-34.

Benedek, D. - Lelkes, O. - Scharle, Á. - Szabó, M. (2006): A magyar államháztartási bevételek és kiadások szerkezete 1991-2004 között [The structure of Hungarian budgetary revenues and expenditures, 19912004]. Közgazdasági Szemle 53(2): 119-143.

Bobak, M. - Marmot, M. (1996): East-West Mortality Divide and its Potential Explanations: Proposed Research Agenda. British Medical Journal 312(7028): 421-425.

Bohk, C. - Rau, R. (2015): Impact of Economic Conditions and Crises on Mortality and its Predictability. Kolner Zeitschrift Fur Soziologie Und Sozialpsychologie 67: 271-294.

Booth, H. - Hyndman, R. J. - Tickle, L. - de Jong, P. (2006): Lee-Carter Mortality Forecasting: A MultiCountry Comparison of Variants and Extensions. Demographic Research 15: 289-310.

Booth, H. -Maindonald, J. - Smith, L. (2002): Applying Lee-Carter Under Conditions of Variable Mortality Decline. Population Studies 56: 325-336.

Booth, H. - Tickle, L. (2008): Mortality Modelling and Forecasting: a Review of Methods. Annals of Actuarial Science 3(1-2): 3-43.

Brouhns, N. - Denuit, M. - Vermunt, J. K. (2002): A Poisson Log-Bilinear Regression Approach to the Construction of Projected Lifetables. Insurance: Mathematics and Economics 31(3): 373-393.

Buda, B. (2001): Az Öngyilkosság [Suicide]. Budapest: Animula Egyesület.

Caselli, G. - Meslé, F. - Vallin, J. (2002): Epidemiologic Transition Theory Exceptions. Genus 9-51. https:// pdfs.semanticscholar.org/1dd0/f6a675b47b0bb7aa4b01c8d9fd392c1bdae5.pdf, accessed 22/04/2021.

Csaba, L. (2007): The New Political Economy of Emerging Europe. Budapest: Akadémiai Kiadó. http://perg. ceu.hu/sites/default/files/publications/the-new-political-economy-of-emerging-europe.pdf.

Dãnãcicã, D.-E. (2006): Cluster Analysis in the Study of Life Quality on the Central and Eastern European Countries. Zagreb International Review of Economics \& Business 9(1): 45-60. 
Deaton, A. - Paxson, C. (2004): Mortality, Income, and Income Inequality over Time in Britain and the United States. In: Wise, D.A. (ed): Perspectives in the Economics of Aging. Chicago: Chicago University Press, pp. 247-286.

Dyba, W. - Loewen, B., Looga, J. - Zdražil, P. (2018): Regional Development in Central-Eastern European Countries at the Beginning of the 21st Century: Path Dependence and Effects of EU Cohesion Policy. Quaestiones Geographicae 37(2).

Fazekas, K. (1997): Válság és prosperitás a munkaerőpiacon [Crisis and prosperity on the labour market]. Tér És Társadalom 11(4): 9-24.

Fazekas, K. - Scharle, Á. (2012): Diagnosis and Lessons. In Fazekas, K. - Scharle Á. (eds.), From Pensions to Public Works. Budapest: MTA KRTK, pp. 1-19.

Fihel, A. - Okólski, M. (2019): Demographic Change and Challenge. In: Okólski, M - Fihel, A. (eds): Social and Economic Development in Central and Eastern Europe. Abingdon: Routledge, pp. 101-132.

Fihel, A. - Pechholdová, M. (2017): Between 'Pioneers' of the Cardiovascular Revolution and its 'Late Followers': Mortality Changes in the Czech Republic and Poland since 1968. European Journal of Population 33(5): 651-678.

Golinelli, R. - Rovelli, R. (2002): Painless Disinflation? Monetary Policy rules in Hungary, 1991-99. Economics of Transition 10(1): 55-91.

Grigoriev, P. - Meslé, F. - Shkolnikov, V. M. - Andreev, E. - Fihel, A. - Pechholdova, M. - Vallin, J. (2014): The Recent Mortality Decline in Russia: Beginning of the Cardiovascular Revolution? Population and Development Review 40(1): 107-129.

Hatzopoulos, P. - Haberman, S. (2013): Common Mortality Modeling and Coherent Forecasts. An Empirical Analysis of Worldwide Mortality Data. Insurance: Mathematics and Economics 52(2): 320337.

HMD. (2020): Human Mortality Database. University of California, Berkeley (USA), and Max Planck Institute for Demographic Research (Germany).

Hyndman, R. J. - Booth, H. - Yasmeen, F. (2013): Coherent Mortality Forecasting: The Product-Ratio Method with Functional Time Series Models. Demography 50(1): 261-283.

Hyndman, R. J. - Ullah, S. (2007): Robust Forecasting of Mortality and Fertility rates: a Functional Data Approach. Computational Statistics \& Data Analysis 51(10): 4942-4956.

Johansson, S.-E. - Sundquist, J. (1999): Change in Lifestyle Factors and Their Influence on Health Status and All-Cause Mortality. International Journal of Epidemiology 28(6): 1073-1080.

Józan, P. (2002): A halandóság alapirányzata a 20. században, és az ezredforduló halálozási viszonyai Magyarországon [Mortality trends in the 20th century and mortality rates in Hungary during the Millennium]. Magyar Tudomány 4: 419-439.

Józan, P. (2003): Az Alkohol Hatása a Halandóságra Magyarországon, 1970-1999 [The Impact of Alcohol on Mortality in Hungary, 1970-1999]. Budapest: Központi Statisztikai Hivatal.

Józan, P. (2004): Csökkenő kardiovaszkuláris mortalitás, javuló életkilátások, új epidemiológiai korszak kezdete Magyarországon [Decreasing cardiovascular mortality, new life prospects and trhe begining of a new epidemiological age in Hungar]. Magyar Epidemiológia 1(1): 31-48.

Józan, P. (2008): Válság és megújulás a második világháború utáni epidemiológiai fejlôdésben Magyarországon [Crisis and renewal in post-World War Two epidemiological development in Hungary]. Budapest: MTA Társadalomkutató Központ.

Kovács, K. (2012): Társadalmi egyenlötlenségek a mortalitásban és az okspecifikus halálozási minták változása - egy közös elméleti keret kialakítása felé [Social inequalities in mortality and changes in reason-specific mortality patterns - towards a common theoretical framework]. Demográfia 55(1): 5-43. 
Lackó, M. (2010): A magyarországi rossz egészségi állapot lehetséges magyarázó tényezői. Összehasonlító makroelemzés magyar és osztrák adatok alapján, 1960-2004 [Potential explanations for low levels of health in Hungary. Comparative macro-analysis using Hungarian and Austrian data, 1960-2004]. Közgazdasági Szemle 57(9): 753-778.

Lee, R. C. - Miller, T. (2001): Evaluating the Performance of the Lee-Carter Method for Forecasting Mortality. Demography 38(4): 537-549.

Lee, R. D. - Carter, L. R. (1992): Modeling and Forecasting U. S. Mortality. Journal of the American Statistical Association 87(419): 659-671.

Li, N. - Lee, R. (2005): Coherent Mortality Forecasts for a Group of Populations: An extension of the LeeCarter method. Demography 42(3): 575-594.

Luy, M. - Wegner, C. - Lutz, W. (2011): Adult Mortality in Europe. In: Rogers, R. G. - Crimmins, E. M. (eds) International Handbook of Adult Mortality. Cham: Springer, pp. 49-81.

Májer, I. - Kovács. (2011): Élettartam-kockázat-a nyugdíjrendszerre nehezedõ egyik teher [Life expectancy risk as a burden on the pension system]. Statisztikai Szemle 89(7-8): 790-812.

Meslé, F. - Vallin, J. (2012): Mortality and Causes of Death in 20th-Century Ukraine. Cham: Springer Science \& Business Media.

Meslé, F. (2004): Mortality in Central and Eastern Europe: Long-term Trends and Recent Upturns. Demographic Research 2: 45-70.

Meslé, F. - Vallin, J. (2002): Mortality in Europe: the Divergence Between East and West. Population 57(1): 157-197.

Meslé, F. - Vallin, J. (2017): The End of East-West Divergence in European Life Expectancies? An introduction to the Special issue. European Journal of Population 33(5): 615-627.

Muraközy, L. (2008): Magyarország felemelkedése és hanyatlása [The rise and fall of Hungary]. Közgazdasági Szemle 55(2): 149-168.

Olshansky, S. J. - Ault, A. B. (1986): The Fourth Stage of the Epidemiologic Transition: The Age of Delayed Degenerative Diseases. The Milbank Quarterly 64(3): 355-391.

Petneházi, G. - Gáll, J. (2019): Mortality Rate Forecasting: Can Recurrent Neural Networks Beat the LeeCarter Model? Arxiv.Org.preprintarXiv:1909.05501.

Prentice, J. C. - Pizer, S. D. (2007): Delayed Access to Health Care and Mortality. Health Services Research 42(2): 644-662.

Rabbi, A. M. F. - Mazzuco, S. (2018): Mortality and Life Expectancy Forecast for (Comparatively) High Mortality Countries. Genus 74(1): 1-28.

Renshaw, A. - Haberman, S. (2006): A Cohort-Based Extension to the Lee-Carter Model for Mortality Reduction Factors. Insurance Mathematics and Economics 38(3): 556-570.

Renshaw, A. - Haberman, S. (2011): A Comparative Study of Parametric Mortality Projection Models. Insurance: Mathematics and Economics 48(1): 35-55.

Rychtaríková, J. (2004): The Case of the Czech Republic. Determinants of the Recent Favourable Turnover in Mortality. Demographic Research 2: 105-138.

Scheiring, G. - Irdam, D. - King, L. (2018): The Wounds of Post-Socialism: a Systematic Review of the Social Determinants of Mortality in Hungary. Journal of Contemporary Central and Eastern Europe 26(1): 1-31.

Shair, S. - Purcal, S. - Parr, N. (2017): Evaluating Extensions to Coherent Mortality Forecasting Models. Risks 5(1): 16.

Shang, H. L. (2015): Statistically Tested Comparisons of the Accuracy of Forecasting Methods for AgeSpecific and Sex-Specific Mortality and Life Expectancy. Population Studies 69(3): 317-335. 
Šimpach, O. (2014): Detection of Outlier Age-Specific Mortality Rates by Principal Component Method in R Software: the Case of Visegrad Four Cluster. The 8th International Days of Statistics and Economics, pp. 1505-1515.

Sommers, B. D. - Long, S. K. - Baicker, K. (2014): Changes in Mortality after Massachusetts Health Care Reform: a Quasi-Experimental Study. Annals of Internal Medicine 160(9): 585-593.

Spéder, Z. - Paksi, B. - Elekes, Z. (1998): Anomie and Stratification at the Beginning of the Nineties. In@ Kolosi, T. - Tóth, I. G. - Vukovich, G. (eds): Social Report. Budapest: TÁRKI, pp. 490-513.

Stuckler, D. - King, L. - McKee, M. (2009): Mass Privatisation and the Post-Communist Mortality Crisis: a Cross-National Analysis. The Lancet 373(9661): 399-407.

Tóth, C. G. (2021): Age- and Gender-Specific Excess Mortality during the Covid-19 Pandemic in Hungary in 2020. MPRA Paper No. 106948.

Valkovics, E. (1999): Halandóság a második világháború után [Mortality after the Second World War]. Statisztikai Szemle 77(1): 16-36.

Vékás, P. (2017): Nyugdíjcélú életjáradékok élettartam-kockázata az általánosított korcsoport-időszakkohorsz modellkeretben [Life expectancy risks of pension payouts in a generalized cohort modell]. Statisztikai Szemle 95(2): 139-165.

Vékás, P. (2018): Változások a halandóságjavulás mintázatában Magyarországon [Changes in the improvement of mortality in Hungary]. Biztositás És Kockázat 5(3): 34-47.

Villegas, A. - Kaishev, V. K. - Millossovich, P. (2015): StMoMo: An R Package for Stochastic Mortality Modelling. In 7th Australasian Actuarial Education and Research Symposium.

Wilmoth, J. (1993): Computational Methods for Fitting and Extrapolating the Lee-Carter Model of Mortality Change. http://www.demog.berkeley.edu/ jrw/Papers/LCtech.pdf, accessed 22/04/2021.

Wood, S. N. (1994): Monotonic Smoothing Splines Fitted by Cross Validation. SIAM Journal on Scientific Computing 15(5): 1126-1133.

Woolhandler, S. - Himmelstein, D. U. (2017): The Relationship of Health Insurance and Mortality: is Lack of Insurance Deadly? Annals of Internal Medicine 167(6): 424-431.

Open Access. This is an open-access article distributed under the terms of the Creative Commons Attribution 4.0 International License (https://creativecommons.org/licenses/by/4.0/), which permits unrestricted use, distribution, and reproduction in any medium, provided the original author and source are credited, a link to the CC License is provided, and changes - if any - are indicated. (SID_1) 